\title{
BARVY, BAREVNÉ VNÍMÁNÍ A KOLOROTERAPIE
}

\author{
Ivan Dylevský
}

7: 1-200, 2005

ISSN 1212-4117

Jihočeská univerzita v Českých Budějovicích, Zdravotně sociální fakulta, katedra preklinických oborů

\section{Co je to barva?}

Slovo barva je mnohoznačné. Barvu má hlas, zvuk hudebního nástroje, sen i podzimní les. Barva může být výrazem životního názoru, vnitřního světa emocí, ale také struktury životního stylu.

Barva je součástí historie lidské společnosti a její vnímání a interpretace ovlivnilo i kulturní dějiny. Barevné vnímání je způsobem vnímání hmotného světa, ale není objektivní vlastností hmoty. Může být nositelkou informací.

Mnohovrstevnost slova (pojmu) barva se odráží i ve fyziologickém účinku barev (resp. barevného světla) na organismus. Jde o velmi obtížně uchopitelný fenomén a chceme-li se dobrat racionálního výkladu vlivu barev na člověka, resp. léčebného efektu koloroterapie, musíme se nejprve pokusit analyzovat jednotlivé převleky, ve kterých barvy hrají své role.

Barva je subjektivní prožitek - vjem. Barva je paradox, který existuje pouze jako světlo. Newtonovský název pro barvu (světlo rozložené hranolem) - spectrum, znamená přízrak, přelud, vidina.

Z fyzikálního a fyziologického hlediska jde v podstatě o schopnost mnohobuněčných živočichů zaznamenat a rozlišit několik vlnových délek viditelné části světelného spektra. Rod Homo je z hlediska vnímání barev „tříbarevný“ jsme trichromáti. Žijeme v barevném světě, ale pro řadu živočichů je tento svět bezbarvý (resp. černobílý). Bud' mono- nebo dichromaticky (jedno-dvojbarevný).

Proč právě člověk vidí barevně?

Ovlivňuje barevný vjem naše chování? Jak vytváříme prožitek barvy? Dochází působením různých barevných podnětů $\mathrm{k}$ fyziologické reakci organismu? Proč?

\section{Barva tvoří dějiny}

Před necelým let začal exodus lidského rodu ze savan východní Afriky a asi před 40000 lety dorazili naši předkové (Homo sapiens sapiens) do prostoru dnešní jižní Ukrajiny a později i na Pyrenejský poloostrov. Nebylo jich mnoho snad několik stovek. Jaké barvy toto lidé viděli? Je bezpečně zjištěno, že jejich svět byl stejně barevný, jako je svět náš - byli již trichromáti. I náš současný nejbližší vývojový souputník šimpanz vidí dokonale barevně.

Jaký vývojový význam má barevné vidění?

Prapůvodní význam barevného vidění byl nepochybně dán významem barev při orientaci v prostředí lesostepí a břehů řek, s enormním rozšířením zelené, modré a červené (květy) barvy. Je totiž prokázáno, že především pohyb předmětů proti pozadí rozlišujeme podle barevného rozdílu, nikoliv pouze podle jeho jasu, textury a prostorové hloubky. Rozlišit barvu tedy znamenalo lokalizovat pohybující se objekt - potravu nebo predátora. Tři typy barevných pigmentů, pomocí kterých začíná proces barevné analýzy světla, jsou určeny třemi geny. Vývojově nejstarší je zřejmě gen pigmentu modré barvy - tedy pigmentu pro kratší vlnové délky. Zjednodušeně lze říci, že naši praprapředci dobře rozlišovali modrou barvu oblohy později došlo k mutaci původně jednotného genu pro červenou a zelenou barvu. Rozštěpení „červeného a zeleného genu, proběhlo dost dávno - asi před padesáti miliony let. Opice tzv. starého světa, lidoopi a všechny rody Homo proto už viděly a vidí trojbarevně. Barevné vidění se stalo tak významným zdrojem informací, že provázelo a stimulovalo evoluci člověka v celém jejím průběhu.

První rozumní lidé zachycovali před 40000 lety své vize černým uhlem a červenou hlinkou. Důvodem menší barevnosti jeskynních obrazů není omezené barevné vidění jejich tvưrců, ale nedostatečná technologie výroby barev. Jakmile byla zvládnuta výroba, barvy se zmnožují a stávají se součástí kultury, jazyka a struktury životního stylu.

Ale také různé interpretace - často paradoxní a významově nejednotné. A právě v historicky nejednotné interpretaci vnímání a individuálně rozdílné odezvě na působení barev spočívá jeden ze základních problémů koloroterapie.

Pokusíme se nejprve shrnout základní údaje o proměnách chápání barevných vjemů - psychologie barev. 


\section{Psychologie barevnosti}

Především je nutné si uvědomit, že světelné, tj. barevné spektrum, se kterým pracuje psychologie, je mnohem širší než fyzikální chápání barev. Zahrnuje i různé barevné odstíny a „barvy“, které vlastně barvami ani nejsou.

Modrá barva. Z evolučního hlediska jde o nejdřive rozlišovaný barevný vjem. Modrá barva moře byla tak emočně intenzivní a jednoznačná, že v podstatě ve všech kulturách je interpretována stejně. Je považována za barvu naděje, víry a stability, senzitivity a loajálnosti.

Je zajímavé, jak se s touto základní barvou vyporááávají hlavní evropské jazyky. Pro modrou jsou $\mathrm{v}$ podstatě dva kořenové výrazy: azur (azura) a cyanus (kyaneos, ceruleus). Azurová barva je perské označení pro blankytnou oblohu a z perštiny převzala tento výraz i řečtina. Ale pro označení modrého moře, používali Řekové slovo kyaneos (kyaneus) - cyanová barva.

Jen dva kořenové výrazy pro základní barvu jsou velmi citlivým indikátorem postavení a významu, který byl odstínům této barvy přikládán. Je př́značné, že barva moře byla barvou naděje a očekávání, ale blankyt byl chápán jako symbol nevinnosti. $V$ původní křest'anské ikonografii mívala panenská Marie roucho modré - blankytné barvy.

Azurové barvy našly svůj výraz i v heraldice.

Barva oblohy symbolizovala pietu, úctu, věrnost a oddanost. Ve východních kulturách se vnímání a posuzování modré barvy neliší od evropských standardů. Vysocí úředníci čínského císařství nosili pláště modré - azurové barvy. Modrá byla barvou egyptského Amóna, mexického Quetzalcoatla i germánského Odina.

Z psychologického hlediska je vnímání modré barvy interpretováno shodně: barva snižuje psychické napětí a uklidňuje. U citlivých osob bylo $\mathrm{v}$ „modrém prostředí “ pozorováno snížení tepové frekvence a lehký pokles tlaku. Přes tyto převážně sedativní efekty, vyvolává modrá barva spánkový diskomfort, poruchy usínání, neklid a přerušovaný spánek. Odmítají ji lidé originální, vnitřně nejistí i lidé nespokojení se svými vztahy.

Červená barva patří - společně s oranžovou - mezi dlouhovlnné barvy spektra. Savci jsou většinou dichromatičtí, tj. mají oční pigment pro krátké (modrou) a dlouhé vlnové délky (červenou). Geneticky starší je gen pro modrou barvu; nepatrně mladší je gen červeného pigmentu, ze kterého mutací vznikl gen zelené. Geneticky kódované jsou tedy u člověka tři pigmenty: modrý, červený, zelený. Označení „gen pro barvu“ je zapotřebí chápat jako zjednodušení
- barva jako taková není prímo kódována.

Historické chápání červené barvy je vzácně stabilní, ale dvojznačné. Červená byla vždy barvou dobyvatelů, barvou hrdinství, vitality a revoluce. Červená je barvou utrpení, smrti, barvou pekla a d'ábla. Ale také lásky, plodnosti a mučednictví. Obdobně byla přijímána i východními kulturami, kde byla symbolem dlouhého života a stavu před změnou, zlomem, revolucí. Je to energická a rázná barva.

Ve všech etnických oblastech byla zároveň signální barvou, barvou rizika, zákazu, pohotovosti, ale i sexu.

Ovlivnění lidské psychiky je také interpretováno v podstatě shodně: červená irituje, dráždí a vyvolává neklid. Zrychluje tepovou frekvenci, navozuje pocit tepla a u citlivých osob bylo zaznamenáno i mírné kolísání tlaku. Působení červené vyvolává růst kožního odporu a zvyšuje frekvenci elekroencefalografických vln.

Signální - výstražný charakter má odstín červené barvy, který se blíží barvě krve. Jiné odstíny červené byly vnímány jinak.

Okr - železitá, žlutá až hnědá hlinka, která pálením získává červený odstín, patří k nejstarším barvám, kterými paleolitický člověk zachycoval lovecké scény a postavy lidí i zvířat. Okrem se před více než 40000 lety lidé tetovali. Ve výtvarných projevech zřejmě nešlo o zvláštní psychologický význam, který by byl této barvě prrikládán, ale spíše o dostupnost barevné hlinky a její snadné zpracování. Technologie ostatně dost často ovlivňovala „společenské postavení“ barvy.

Purpur, šarlat a nach jsou sytě červené barvy s různě intenzivním nádechem fialové. Purpur byl vždy vnímán jako symbol síly, vůdcovství a respektu. Původní význam ale nebyl vysloveně imperiální. Ve starověkém Řecku byla „porphura“ získávána dost pracným způsobem z ryb. Byla to velmi drahá barva, a proto bývala vyhrazena zámožným patronům - opatrovníkům sirotků. Původně tedy nešlo o moc, ale o pečovatelství.

Pro Ř́many byl purpur císařskou barvou a ve středověku se postupně přidala i symbolika kardinálské, církevní moci. Čínský smysl pro strukturovanou společnost přiřadil purpur synovci císaře a literátům.

Nachové odstíny barev působí vznešeně, chladně a odtažitě. Čím více je v této kompozitní barvě fialové, tím je výsledný dojem studenější a smutnější.

Zelená barva je velmi dominantní. Výrazy pro zelenou barvu nejsou sice $\mathrm{v}$ hlavních jazykových skupinách př́liš bohaté, ale historicky jde 
obvykle o první slova nově se formujícího jazyka. Ve výkladu zelené barvy se starověk a raný středověk př́liš nerozcházejí. Keltové považovali zelenou za barvu života, plodnosti, růstu, jara, fertility, př́rody, harmonie a barvu naplnění. Zelená byla barvou řecké Afrodity i římské Venuše. Aztékové vkládali mrtvým panovníkům do hrudi zelený kámen a Egypt'ané vyráběli posvátné brouky (hovnivály) ze zeleného smaragdu.

Zajímavý je vztah křest’anství k zelené symbolice. První křest’anské tisíciletí považovalo ve shodě s pohanským světem - zelenou za barvu plodnosti a života. Sv. Marie byla často zobrazována alespoň se zelenou pokrývkou hlavy. $\mathrm{Na}$ konci prvního milénia byla zelená barva $\mathrm{z}$ ikonografie postupně vytěsňována; zelené symboly př́iliš prripomínaly pohanství a tlak islámu. Islám považuje zelenou za svatou barvu naděje a veselí. Renezance se opět vrací $\mathrm{k}$ původnímu výkladu a těhotné ženy na obrazech renezančních mistrů oblékají šaty zelených barev. Ve středověké Číně byla zelená dominantní barvou pouze dynastie Ming (1368 - 1644). Ve společenské hierarchii prŕliš významná nebyla - byla barvou plášt'ů nižších úř́edníků.

Psychologický vliv zelené barvy je ve všech kulturních regionech opět interpretován $\mathrm{v}$ podstatě stejně. Zelená uklidňuje, harmonizuje a navozuje relaxovaný stav. Zelená je pokládána za obecně hojivou a regenerační barvu.

Žlutá barva provázela Evropany při zábavách a veselicích. Připomíná slunce a život. V Č́ně byla posvátná a od sedmnáctého do dvacátého století byla vyhrazena pro císaře a jeho syny.

Veselá žlutá barva je ve skutečnosti výkladově rozporná. V heraldice je barvou moci, stability, věrnosti, oddanosti, moudrosti a slávy. Byla ale také nařízenou barvou šatů středověkých prostitutek!? Rytírská barva věrnosti tedy zároveň symbolizovala zbabělost, žárlivost, zradu, stárí, úpadek, zánik a nemoc.

Psychologicky je žlutá převážně přijímána jako barva světla, energie, kreativity a dobré nálady.

Obojaké a protichůdné príijimání barev není u žluté nijak výjimečné. Velmi situační pojímání všech základních barev a jejich interpretaci najdeme i u modré, zelené a červené. Zvláště různé odstíny základních barev bývají vykládány velmi tendenčně. Červená může být vnímána nejen jako hrdinský symbol dobyvatele, ale i jako označení pro „krvavého vraha“, nedůstojný „červený nos“ atd. Modrá je sice symbolem „modravých dálek sladkého voláni“", ale také hrůzy nekoneč- ného vodního prostoru, polární zimy a chladného světla.

\section{Nebarevné barvy}

Při výkladu fyziologického a psychologického působení barev se často objevují dvě „barvy - nebarvy“: černá a bílá. Barva je světlo, tj. elektromagnetické záření. Pro černou a bílou neexistuje žádná vlnová délka. Černou barvu má těleso, které úplně pohlcuje světlo, tj. žádné světlo neodráží. Bílá „barva“ je absence barvy, její úplný odraz - reflexe.

Fyzikálně je tedy všechno jasné, fyziologicky je zde ale přece jen problém.

Od narození slepý člověk nevidí „černě“ nevidí nic. Osleplý, ale má představu černé barvy. Černá je pro něho aktivní vjem, který lze registrovat snímáním elektrických potenciálů mozkové kůry. Je čímsi vjemově aktivním, ne chyběním všeho.

Už v knize Genesis se praví: „A viděl Bůh světlo, že bylo dobré; i oddělil Bůh světlo od tmy. “ Tma - černá barva je i v tomto základním textu považována za vjem adekvátní světlu - ne však identický se světlem.

Fyziologická interpretace vnímání černé barvy je zatím nejasná. Bílá podobné stavy nevyvolává. Osleplý člověk si pamatuje bílou barvu obvykle jako barvu sněhu - s modrým nádechem. Při asociování bílé barvy se aktivují korové okrsky pro modrou barvu (PET). Z hlediska koloroterapie jde o velmi zajímavé zjištění, ale při současných znalostech fyziologie barevné analýzy $\mathrm{v}$ mozkové kůr̆e, je tento poznatek zatím neinterpretovatelný.

Srozumitelná je naopak symbolika obou vjemů.

Černá barva je u většiny etnik spojena se smrtí, smutkem, zánikem a odříkáním. Spojení černé barvy a smrti má prastarý, semitský původ. Semitské kmeny pokrývaly tvář zemřelých černou barvou. Smyslem této procedury bylo zamaskování tváře poznamenané smrtí. Rituál byl přenesen na pozůstalé - zakrytí tváře černou rouškou nebo závojem nahrazovalo líčení mrtvých. Zakrytím byla symbolizována ztráta tváré a zároveň se černá barva stávala znakem celé skupiny truchlících. Proto je i dnes v evropském křest’anském světě běžné barevné odlišení smutečních hostů.

Křest'anství, ale i konfuciánská Čína považovaly černou barvu za d'ábelskou. Číňané zůstali důslední - černou obecně nemají rádi. Evropané chápou černou barvu opět dvojznačně. 


\section{Jak vidí mozek?}

Podivná otázka. I bez neurofyziologických rozborů lze podstatu problému vyjádřit také takto: „Oči jsou $\mathrm{k}$ vidění, uši k slyšení a mozek to zváží.“

Jde o velmi komplikované záležitosti, které vyžadují značné znalosti $z$ neuroanatomie a neurofyziologie. Přesto se pokusme celý problém barevného vidění alespoň přiblížit.

Světlo dopadá na sítnici - vnitřní vrstvu oka, která vystýlá především zadní partie oční koule. Sítnice je svoji stavbou nervová tkáň; tkáň vysunutá mimo centrální nervový systém. V sítnici je mnoho typů buněk - pro barevné vidění slouží $6-7$ milionů čípků. Čípky jsou buňky kónického tvaru, které mají ve svých zevních partiích pigment citlivý na červenou, zelenou nebo modrou část viditelného světelného spektra.

Světlo je elektromagnetické záření, které má vlnovou i částicovou (fotonovou) povahu. Fotony dopadající na čípky vyvolávají změnu tvaru molekuly některého ze tř́ pigmentů. $\mathrm{Na}-$ príklad červená barva (vlnové délky 660 - 760 $\mathrm{nm})$ mění tvar molekuly pigmentu pro tuto vlnovou délku. Změna tvaru vyvolá elektrochemické změny, jejichž výsledkem je proud elektrických vzruchů, které jsou zrakovým nervem vedeny do mozku. Určitá barva (stejně jako tvar, intenzita světla a množství dalších parametru) jsou v podstatě zakódovány do elektrických signálů, které musí jednotlivé mozkové struktury opět dekódovat a vytvořit výsledný vjem. Oko bez mozku je jako fotografický aparát bez citlivého filmu a bez př́jemce (interpreta) obrazu.

Zrakový nerv převádí barevné informace ze sítnice nejprve do určitých struktur mezimozku. Z hlediska koloroterapie jde o velmi významný spoj. Barevné informace se tak dostávají do míst, odkud je modulován tzv. autonomní nervový systém (především orgánový řídící systém), systém žláz s vnitřní sekrecí a biologický čas (biorytmus).

Jaké důsledky má toto zapojení ?

Neurony mezimozku mají sice svůj, geneticky zakódovaný program, který se postupně v dětském mozku aktivuje, ale vlastní program se týká pouze rámcových funkcí, které mohou být dost rozsáhle modifikovány např. světlem a snad i barvou.

Pro pochopení několik príkladů.

Z jedné skupiny nervových buněk mezimozku se v pravidelných časových intervalech uvolňuje látka, která reguluje tvorbu hormonu melatoninu v šišince (epifýze). Při nedostatku světla (v noci) se melatoninu tvoří více. Podobně ryt- mická a na světle závislá, je i tvorba řady dalších hormonů. (Viz mezimozek a řízení žláz s vnitřní sekrecí.) Tento typ syntézy hormonů se stabilizuje po narození a udržuje se v závislosti na světelném režimu, kterému jsme vystaveni. U slepců se bud' tyto rytmy vůbec nevytvoŕí, nebo po oslepnutí mizí - desynchronizují se. Pokud světelný režim významněji změníme, musí se celý systém adaptovat. To ale určitou dobu trvá. Proto není radno rychle stř́́dat noční a denní pracovní směny, vést intenzivní jednání po přeletu několika časových pásem apod. Je nutné si také uvědomit, že rytmicita tvorby hormonů má značně široký dopad na celý organismus. Světlem mohou být ovlivněny imunitní reakce (přes hormony kůry nadledvin), regenerační a hojivé procesy (růstový hormon, interleukiny, růstové faktory) i psychické procesy (emoce zprostředkované aktivací mozkové kůry světlem).

Pouze několik - u člověka zcela průkazných účinků světla realizovaných na úrovni mezimozku dovoluje zcela zásadní konstatování:

Fyziologický a léčební efekt fototerapie (světelné léčby) je zcela nepochybný, a fyziologicky, klinicky i anatomicky přesvědčivě dokumentovatelný. Pozor! Předchozí věta mluví o fototerapii.

A právě zde je asi zakopán pes velmi nepřehledné a často si odporující odborné (nemluvě o populárnî) literatury, věnované světelné terapii. Léčebný efekt světla realizovaný centry mezimozku je v podstatě jasný, ale fyziologicky, resp. léčivý efekt jednotlivých barev, je přinejmenším sporný. U člověka nebyl podán prímý důkaz vlivu různých vlnových délek světla (barev) na nervové buňky mezimozku. Stejně tak nejsou tyto buňky ovlivněny tvarem nebo pohybem světelného zdroje. Na základě současných vědeckých poznatků o spojích a funkcích zrakové dráhy a mezimozku, nemůžeme proto efekt koloterapie ztotožnit s efektem světelné terapie. Zdánlivě negativní závěr, ale posouvá celý problém o několik pater výše.

Zakončení části zrakové dráhy $\mathrm{v}$ mezimozku je sice $z$ hlediska světelného ovlivnění organismu velmi významné, ale $\mathrm{k}$ analýze barev a jejich „uvědomování“ dochází až v mozkové kůře.

Pokusme se z mezimozku vyjet do korových pater. Pro zrakovou dráhu jsou $\mathrm{k}$ dispozici dva výtahy:

nákladní (velkobuněčný, magnocelulárnî),

osobní (malobuněčný, parvocelulárnî).

Velkobuněčný spoj reprezentuje hlavní složku zrakové dráhy mezi mezimozkem a kůrou. Tímto svazkem (čípky sítnice ð mezimozek ð mozková kůra) jsou vedeny informace, na které 
mozková kůra odpovídá: Kde je to? Malobuněčným spojem jdou informace, na které je ledána odpověd': Co je to? Tímto spojem jdou údaje o barvách.

Mozková kůra řeší tedy obrazovou informaci, v podobě dvou základních, ale navazujících otázek: Kde a co?

Je to velmi logické a vývojově přesvědčivé. Pro přežití je nejprve nutné analyzovat změnu, obraz vokolí. Teprve potom má smysl se zabývat zjištěním, co se to děje a jakou to má barvu.

Oba výtahy jezdí do kůry současně, ale každý veze jiný náklad. Co se dále děje s obrazem a zvláště s barevnými vjemy $\mathrm{v}$ mozkové kưřre, je zatím předmětem sice velmi intenzivního, ale přece jen počátečního výzkumu.

Nové technologie funkční magnetické rezonance i starší výzkumné postupy dovolují zatím dílčí závěry. Omezíme se na údaje o analýze barev.

Zraková dráha ve svém posledním úseku končí $\mathrm{v}$ rozsáhlé oblasti kưry, především $\mathrm{v}$ kưře mozkového laloku. Část vláken jde i do kưry spánkového laloku. $\mathrm{V}$ nedávné době byla popsána korová oblast na rozhraní spánkového a týlního laloku, která je zřejmě odpovědná za analýzu barevných informací, spojení barvy a tvaru objektu a pomocí intrakortikálních spojů i za vytváření barevných představ a komplexních asociací barvy a zvuku.

Klíčem k poznání účinků koloroterapie a vlivu barev na psychiku a biologické reakce lidského organismu, je zřejmě mozková kůra.

Množí se údaje o funkční specializaci nervových buněk „barevné kůry“. Tj. schopnosti neuronů číst základní barvy a následně skládat různé barevné kompozice. Asociační spoje mezi korovými poli (týlní ð spánkový lalok) přinášejí první informace i o vniku zvukového vjemu, který může doprovázet barevné obrazy. Zraková kůra (včetně oblastí pro analýzu barev) má rozsáhlé spoje nejen s mezimozkem (a tedy i se systémy, které jsou odtud řízeny), ale i s tzv. limbickým systémem. Tento komplex různých struktur a spojů centrálního nervového systému generuje stavy, které nazýváme emoce - nálady. O emočním vlivu barev jsme již mluvili.

\section{Na konci a na začátku}

Celou rozsáhlou problematiku fyziologie a psychologie barev, fototerapie a koloroterapie by bylo možné shrnou do dvou otázek:

Otázka první. Existují neurofyziologické a klinické poznatky opravňující použití fototerapie?

Odpověd': Ano, a jsou zcela přesvědčivé.

Otázka druhá: Existují neurofyziologické a klinické poznatky opravňující použití koloroterapie?

Odpověd': Ano, klinické poznatky jsou přesvědčivé. Neurofyziologické poznatky neodporují klinickým zkušenostem. Poznatky z několika posledních let výrazně zpřesňují znalosti mechanismů působení barev, ale další studie musí řadu skutečností ještě vyjasnit.

Nakonec je zapotřebí alespoň zmínit i další skupinu otevřených problémů. Předchozí výklad se zaměřil na cestu barvy ze sítnice do mozkové kůry. Touto cestou mohou jednotlivé barvy modulovat funkce centrálního nervového systému, a jeho prostřednictvím např. zvyšovat imunitní odolnost organismu. Jaký je ale mechanismus lokálního působení třeba červené barvy?

Zvýšení tepové frekvence, kožního odporu, změny elektroencefalografického záznamu atd., můžeme hledat v celostním působení této barvy. Pacient červené světlo lampy vidí. Lokálně působí červené světlo např. překrvení tkáně. Bude místně i celkově stejně reagovat slepý člověk?

Informací o těchto procesech je velmi málo. Z minima údajů lze dovodit, že celostní reakce slepých je přece jen jiná - chybí vidění barev. Lokální reakce je u nevidomých stejná jako u vidících. Je zde tedy i místní, fyzikální efekt koloroterapie. Objektivní údaje jsou o hloubce průniku základních barev (různých vlnových délek) do tkání. Platí, že energie fotonů roste s klesající vlnovou délkou světla. Další biologické efekty $\mathrm{v}$ ozářeném okrsku tkáně je ale nutné dále studovat.

Nic z toho neměnína základním pravidle celé praktické medicíny: „Nepoškodit, ale jednat, i když nevím.“ 